\title{
Development Models for the Brazilian Countryside
}

\author{
Paradigmatic and Territorial Disputes
}

\author{
by \\ Bernardo Mançano Fernandes \\ Translated by \\ Laurence Hallewell
}

Problems of land use and ownership result from the inequalities caused by the hegemonic form of capitalism, agribusiness. A possible alternative model has yet to be worked out, and there is a fundamental need to reflect on the struggle against the hegemony of capitalism and how to safeguard the interests of the peasantry. From this perspective, the agrarian question should be considered as a conflict between those favoring the interests of the peasantry and family farming and those favoring agribusiness. A paradigmatic debate about the roles of the Brazilian state, agribusiness, and the peasant movements in formulating public policy shows that the potential for the peasantry to grow food is threatened by the concentration of power, landownership, capital, technology, and wealth. Unless there is a change in the development model, the prospect is increasing inequality. The experiment with having two government ministries for agriculture is an important step in the shaping of policies to support family farming.

Os problemas com uso e propriedade da terra são resultados das desigualdades causadas pelo modelo capitalista hegemônico denominado agronegócio. Um possível modelo alternativo está sendo gestado e há necessidade de refletir sobre a luta contra a hegemonia do capitalismo e como salvaguardar os interesses dos camponeses. A partir desta perspectiva, a questão agrária deve ser considerada como conflitualidade permanente entre os interesses dos camponeses ou agricultura familiar e os interesses do agronegócio. O debate paradigmático contribui para compreender o papel do Estado brasileiro, do agronegócio e dos movimentos camponeses na formulação de políticas públicas. Também mostra que as possibilidades de criação de um modelo de desenvolvimento do campesinato está ameaçado pela concentração de poder, propriedade da terra, capital, tecnologia e riqueza nas mãos do agronegócio. Se não houver uma mudança com a criação de um modelo de desenvolvimento voltado aos interesses da agricultura camponesa, a perspectiva é de aumento da desigualdade. A experiência de ter dois ministérios para a agricultura é condição fundamental na definição de políticas de apoio à agricultura camponesa e familiar.

Keywords: Peasantry, Agribusiness, Paradigm, Territory, Development

Bernardo Mançano Fernandes is a professor in the graduate program in geography at the Presidente Prudente and São Paulo City campuses of the Universidade Estadual Paulista and coordinator of the UNESCO Chair in Territorial Development and Education for the Countryside. Laurence Hallewell was, until his retirement, Latin American area librarian at Columbia University. 
The problem of the expropriation of small landowners under capitalism can be approached from two different perspectives - the agrarian question and the nature of capitalism — and solving it will require challenging our capitalist society. Capitalist agriculture has created agribusiness, the most efficient form of farming, and within it smallholdings can be tolerated only in a subordinate position. The peasantry, agribusiness, government, and political parties have long debated what model to follow, and their projects, public policies, actions, and discussions have sought to make their preferences explicit. The universities have contributed research on the results, actual and potential, of government policies. Articles and books have been produced on the different models, providing interpretations of the situation based on paradigmatic assumptions that are used in training future professionals. This paper will discuss these models through reflection on the Brazilian agricultural and livestock census of 2006 and brief analyses of the situation in the country's various regions.

Paradigms are views of the world, mental constructs, that are used in the contest of ideas to defend or impose the various intentions that underlie interpretive models. They represent interests and ideologies, desires and decisions made effective on the ground by public policies in accordance with the objectives of social classes. It is through paradigms that social scientists interpret reality and seek to explain it. To do so, they choose sets of variables in terms of their perspectives and histories that define the results they seek to demonstrate in political terms, always, of course, respecting theoretical and methodological rigor.

Territories must be understood not as unitary units but as multidimensional. Fundamental to the concept of a territory is land as a space delimited by power relations in the form of property and disputed by different social classes (Elden, 2010; Fernandes, 2008c). It is in these spaces that different relationships and social classes constructing their own territories are produced. Spaces, relationships, classes, and territories are inseparable concepts, since the destruction of a class means that its territory disappears. Changes in agriculture lead to a constant dispute over land due to differences in interests of peasants, corporations, and government and also differences among peasants themselves, between peasants and indigenous people, and between indigenous people and agribusiness. In this article I shall concentrate on the disputes between peasants and agribusiness.

These disputes are seen overwhelmingly as obstacles to development. Elsewhere (Fernandes, 2008a) I have defined conflict in such a way as to allow us to overcome the idea that conflict in itself hinders development. Even if conflict were an obstacle, the question would be to what sort of development. Just as the peasantry is against the development of agribusiness, so agribusiness is opposed to any expansion of peasant farming. Since conflict is inherent in development, it is important that we understand the characteristics of that conflict. Land, politics, and social relations are basic attributes in defining conflict. The different social relations formed among the peasantry and by agribusiness lead to different ways of using the land that require different development policies. Conflict is therefore manifested in disputes over land, territory, policies and technologies, markets, and conditions of development.

Looked at in this way, conflict becomes not an obstacle but a political argument over bimodal development: peasant and agribusiness. The state alone, based on democratic government, can mediate conflict such as over public 
policies for development and land management. This is how the paradigmatic debate is conducted, looking for solutions for the problems of differentiated development. In this debate there is never any consensus, just constant conflict. The debate engenders ideas and negotiation that are transformed into policies that promote social change. This does not mean the end of conflict. Instead, it nourishes conflict.

The literature on development and agricultural transformation is replete with instances of the problems in the production of territories created by social relations. This literature has been influential in the formation of public policies for development in agriculture, determining the allocation of resources among specific regions, territories, sectors, cultures, institutions, and so on. This is why it is fundamental that we understand the paradigmatic process, from the way problems are understood to the way policy is implemented. I have taken as a starting point two paradigms - the agrarian question and agrarian capitalismto represent the positions adopted by government at its various levels (national, state, and local), national and international agribusiness corporations, and the various peasant movements.

The paradigm of the agrarian question has the class struggle as its point of departure in explaining land disputes and disagreements over models of development that advocate autonomy for peasants. It is argued that agrarian problems are part of the structure of capitalism, and therefore the struggle against capitalism is looked upon as an attempt to build an alternative society (Fernandes, 2008a). In the paradigm of agrarian capitalism, in contrast, any inequalities created by capitalist relationships are a problem of the current economic situation and can be solved through policies that allow the "integration" of the peasant or family farmer into the capitalist market. This logic sees the peasantry and capital as components of a single political space, part of a single whole (capitalist society), making no distinction between them because the class struggle is not an element of this paradigm (Abramovay, 1992). To sum up, for the paradigm of the agrarian question, the problem arises from capitalism, and for the paradigm of agrarian capitalism, the problem lies with the peasantry.

These paradigms have contributed to the development of different interpretations of Brazilian reality by universities, governments, businesses, agribusiness corporations, and peasant movements. At present, the most influential agribusiness organizations are the Associação Brasileira do Agronegócio (Brazilian Agribusiness Association-ABAG) and the Confederação da Agricultura e Pecuária do Brasil (Farming and Livestock Confederation of Brazil-CNA). Among peasants' organizations we have Via Campesina, made up of the Movimento dos Trabalhadores Sem Terra (Landless Workers' Movement-MST), the Movimento dos Pequenos Agricultores (Small Farmers' Movement-MPA), the Movimento dos Atingidos por Barragens (Movement of Those Affected by Dam Building-MAB), the Movimento das Mulheres Camponesas (Peasant Women's Movement), and the Comissão Pastoral da Terra (Pastoral Land Commission-CPT); the Confederação dos Trabalhadores na Agricultura (Agricultural Workers' Confederation-CONTAG); and the Federação Nacional dos Trabalhadores e Trabalhadoras na Agricultura Familiar (National Federation of Family Farm Workers-FETRAF). There are two federal ministries concerned with rural development policy: the Ministry of Agriculture, Livestock, and Food Supply and the Ministry of Agrarian 
Development. Among the more influential universities are the Universidade Federal Rural do Rio de Janeiro, the Universidade deSão Paulo, the Universidade Estadual Paulista, and the Universidade Federal do Rio Grande do Sul.

The two paradigms are sharply distinguished in terms of their understandings of "agribusiness" and "peasant" or "family farming." For both the agribusiness organizations and the Ministry of Agriculture, "agribusiness" is the totality of crop cultivating, livestock raising, and fishing and their industrial, commercial, financial and technological components, capitalist and noncapitalist, large and small. (This definition is also accepted by the CONTAG and the FETRAF.) For the Via Campesina, "agribusiness" means capitalist business corporations that produce commodities by means of large-scale monoculture, mainly for export, while the peasants are involved in small-scale systems based on diversity and local markets-a totally different approach.

"Family farming" is defined by Law No. 11,326 of July 24, 2006, which regards as a family farmer anyone who uses the labor of his own family on his own property of no more than four fiscal units (a unit, expressed in hectares, established by each county on the basis of its predominant type of exploitation and the income produced). This paradigm regards the peasant who has acquired some capital and entered the capitalist marketplace as having turned into a family farmer. Seen from this standpoint, the peasant and the family farmer are quite different from each other, but in fact this is a misunderstanding. They are not really different entities; it is only the form of the subordination of the peasantry that distinguishes them. The peasant is and always has been a family farmer. Family farmers constitute a social class differentiated from the managers and owners of agribusinesses. Besides their differences in social position and in politics, these two classes also differ with regard to income and other economic advantages. This is something beyond question, as was well demonstrated by the research published in Martins's 1986 work O cativeiro da terra, based on the theories of Karl Marx, Rosa Luxemburg, and the like.

Conceiving agribusiness as a totality, the paradigm of agrarian capitalism aligns capital with the state in a strategy that places the two at the center of the paradigmatic debate. Accepting capitalist agriculture as the only development model has been the historical posture of the Brazilian state. Even the coming to power of a member of the working class in the person of Luiz Inácio Lula da Silva of the Partido dos Trabalhadores (Workers' Party-PT) has done nothing to change this situation, and indeed the influence of agribusiness has increased. Defining everyone in the industry simply as a farmer conceals all the differences due to power relationships that have produced their inequalities. Materials issued by institutions that employ this definition are always saying that any division of farmers into capitalists and family farmers is impossible (see Navarro, 2010), but this argument can no longer be made. One outstanding example is the existence of two separate ministries for dealing with the development of agriculture: the Ministry of Agriculture (now the Ministry of Agriculture, Livestock, and Food Supply), which is the ministry of agribusiness and has always defended the interests of the big corporations, and the Ministry of Agrarian Development, which was created after the 1996 massacre of 19 peasants at Eldorado dos Carajás and has become important in the development of peasant agriculture. Even the latter argues that family farming is part of agribusiness, but in preparation for the agricultural census of 2006 it required 
that the Instituto Brasileiro de Geografia e Estatística emphasize the output of family farms. For the first time in Brazil's history, the census (IBGE, 2009a; 2009 b) was divided into two parts, one on family farming and the other on "non-family farming" (to avoid the term "agribusiness"). "Agribusiness" (or "corporate agriculture") and "family farming" are concepts recently created to refer to capitalist and peasant agriculture respectively. The use of these terms is part of the contest between two paradigms that seek either to play down or to underline the role of social class in rural land development. Analyses of the differing contributions of peasant and capitalist agriculture based on the agricultural census have been carried out by the geographer Ariovaldo Umbelino de Oliveira since the 1980s to show the important contribution of the peasantry to the country's development (Oliveira, 1991; 2003).

This new way of publishing census data provoked an immediate reaction from the CNA and the ABAG and from the Ministry of Agriculture, creating enormous unease within the Lula administration over the public display of the conflict between ministries in a government that had always tried to support the interests of agribusiness. The upshot was that the CNA engaged a research institute to undertake an analysis of the census and produce results emphasizing the role of agribusiness (CNA, 2010). The authors of this analysis used a different methodology and different variables such as the contribution of different producers to the GDP and their participation in the Programa Nacional de Fortalecimento da Agricultura Familiar (National Program for Strengthening Family Farming-PRONAF). Since agribusiness controls 85 percent of the agricultural credit and 76 percent of the cultivable area, producing 62 percent of the GDP and employing 26 percent of the labor power, these criteria are more favorable than variables such as the diversity and quantity of regional production.

The position adopted by agribusiness led to the alignment of Via Campesina, the CONTAG, and the FETRAF with the Ministry of Agrarian Development, making it clear that the perspectives of the parties involved reflected the different development models they favored and, consequently, the different territories they occupied. On the one side we have the hegemony of agribusiness and its refusal to contemplate any development model except that of the large-scale export of agricultural commodities, with extensive use of toxic chemicals for pest control on genetically engineered crops destined for the world market. On the other side is the model worked out by Via Campesina of food self-sufficiency, emphasizing local production within Brazil and restoration to the state of control over food production and distribution through agricultural development policies based on ecologically sound farming on a small scale for local markets. These were some of the references used to clarify the differences between agribusiness and traditional farming in he IBGE's 2006 agricultural census.

\section{LAND DISPUTES BETWEEN PEASANT MOVEMENTS AND AGRIBUSINESS}

Brazil is a continent-sized country, the fifth-largest in the world, with a huge potential for food production, and its inequalities are as enormous as its physical extent. These inequalities have arisen though the dominance of the agribusiness model in the development of its agriculture. This model controls the land 
in two ways: through monopoly ownership of peasants' holdings (as Oliveira [1991] has emphasized) and through the imposition of production technologies on the peasant families whose income it capitalizes. This relationship between capital and the peasantry produces a "subsistence paradox" in which the latter's output appears in the economic results of agribusiness and the majority of the wealth generated by the peasants is diverted into the profits of the corporations that process and sell what the peasants produce. These processes intensify the inequalities that arise from the broad expansion of capital, which concentrates ownership of land and technologies and therefore wealth. They generate modernity and backwardness through their exploitation of the land, whereby the inhabitants are excluded from any autonomy and subjugated to the hegemonic model of development (Oliveira, 2003). For the paradigm of agrarian capitalism, the exodus from the countryside and the concentration of ownership of land and technology and therefore of wealth are part of the "natural" process of the modernization of agriculture. For the agrarian question paradigm they are problems that can be minimized by government policy and by confronting agribusiness in the fight against capital. These are the political positions of the individuals and institutions represented by the different paradigms in the establishment of the agricultural development policies that I am talking about.

I have analyzed these inequalities by region, examining their sociopolitical, economic, and historical determinants and assuming that unequal development is the normal situation. The extreme disparities between regions that I have observed are responsible for one of the world's most unequal distributions of wealth (with a Gini index of 0.854). Most of the land is controlled by giant business corporations, Brazilian and multinational, and these firms control agricultural development policy, receive most of the agricultural credit, monopolize every stage of the market, and influence the allocation of technology to cultivation and livestock production. Agribusiness in Brazil, by producing predominantly commodities, has become dominant in determining how agriculture is organized, subordinating the family farmers who actually produce most of the food grown for the internal economy. To maintain its dominance, agribusiness presents itself as the only possible model of development, questioning whether family or ecological farming is even worthwhile (Navarro, 2013). It has launched a campaign called Sou Agro (I Am Agribusiness) to create a public image as the provider of economic advantages and the defender of Nature (Bruno, 2012), with no mention of the environmental problems it has created throughout Brazil. It controls one of the most prominent and powerful blocs in Congress, the bancada ruralista (rural bloc), defending the interests of big business. There is a very close relationship between congresspeople from rural constituencies, who are all big landowners, and the agribusiness corporations that fund their political campaigns (Castilho, 2012; Costa, 2012). This bloc looks out for its own interests and those of the national and multinational companies involved in the rural economy, for example, in getting transgenic plants permitted and in determining how the government responds to conflicts among landowners, indigenous people, and peasants (Bruno, 2008). Its hegemony represents the union of landowners and agribusiness, strengthening capitalism and calling into question the argument about the social function of land, which it keeps out of peasant control by land grabbing, leasing, and purchasing (Fernandes, 2013). 
Of Brazil's 851,487,659 hectares, 330 million (39 percent) were being cultivated in 1996-2006 (as opposed to 375 million in 1975-1985). Of the 5,175,489 landholdings recorded, 84.4 percent $(4,367,902)$ were family farms. Although the total area of these farms was only $80,250,453$ hectares ( 24 percent of the cultivated area), they were responsible for 38 percent of the gross annual value of the output (54 billion reais) and employed 74 percent $(12,322,225)$ of the farm workers. Their employee-to-hectare ratio was 15 per 100 in contrast to agribusiness's 2 per 100. Furthermore, for the peasantry their land is both where they produce and where they live, while for agribusiness the land is only the workplace.

According to the analysis of Alves and Rocha (2010), only 8.19 percent $(423,689)$ of Brazil's 5,175,489 farms create 84.89 percent of the value of the total product. Even worse, around 11.3 million rural inhabitants live on 3,775,826 farms and are left with just 4.03 percent of the wealth produced, and the families living on 2,014,567 farms have incomes of half the statutory minimum wage or less. Most of farms with the smallest share of the wealth are family farms. These farmers are responsible for 70 percent of the country's black beans, 87 percent of its cassava, 38 percent of its coffee, and 34 percent of its rice. In animal husbandry, they account for 59 percent of its pork, 50 percent of its poultry, 30 percent of its beef, and 58 percent of its milk. Of the farms producing corn, just 1.57 provide 68.31 percent of the national crop, and 19.59 of dairy farms produce 73.3 percent of the milk.

The Brazilian agrarian sector is a paradox. A small proportion of the rural population controls most of the resources employed in agriculture and the wealth produced while 2 million peasant families, despite producing more than a third of the gross income of the sector, have monthly incomes of around US $\$ 15$ and have to live on government handouts. One response to this situation is to advocate the elimination of the less-productive farms. Another is to favor policies that would broaden the participation of farmers in production and in sharing the wealth produced, such as land reform and an increase in the availability of agricultural credit.

There are regional differences in government policies and the requirements of national and transnational corporations and differences on a smaller scale in the participation of other institutions. The unions and the peasant organizations generally do not come up with development projects of their own but simply accept those presented by the state and by capital. The subordinate position of workers and peasants in the face of the assault by capital is apparent in the fact that government policies overwhelmingly follow the logic of landownership. The differences in position lead to constant class conflict. In examining these regional differences in greater detail, we have many variables to choose among, and particular variables may be more or less important in an individual case. Thus, in addition to the variables specific to each region, its principal commodities, landownership structure, conflicts, and agricultural techniques will furnish reference points for understanding the agrarian question in regional terms.

\section{THE SOUTH AND SOUTHEAST}

The subsistence paradox is most obvious in the South and Southeast, where agriculture is most developed, farmers are best-educated, and there are the highest rates of agrarian conflict. The prospects for reducing this conflict do not 
seem very good, because, according to the 2006 agricultural census, the peasants' share of GDP has declined in the Southeast and remained the same in the South. It is in these two regions that agribusiness was first established and is the most intensive. Soybeans, tobacco, sugarcane, oranges, coffee, corn, milk, poultry, pork, beef, and forest products are the regions' principal commodities, and small farmers contribute chiefly in tobacco production (85 percent), oranges (80 percent), and coffee (42 percent) besides accounting for 60 percent of the black beans, 75 percent of the cassava, and 45 percent of the corn, all grown for the big corporations. Because of the powerful presence of agribusiness, it is in these two regions that smallholders have had the least success in maintaining their position. They have been unable to obtain more land because its price has become too high; according to the 2006 census, family farming made up 80 percent of farms but only 30 percent of the land devoted to agriculture.

São Paulo state has the largest area under citrus in the world: 617,900 hectares, 95 percent of which are holdings of under 35 hectares on which family farming predominates. Marketing and processing are controlled by four corporations that end up with the wealth produced. Concentration of ownership of both land and technology in the hands of agribusiness leads to conflict over exploitation and expropriation. In the latter half of 2009, the MST occupied a stretch of orange groves belonging to the giant Brazilian corporation Cutrale as a protest. Corporations are buying up or acquiring leases on more and more land for crop production. The increase in the production of ethanol and biodiesel has created fierce competition over land. In addition, there is the age-old problem of land racketeering, whereby public land is taken over by big landowners using forged land deeds. Illegal occupation by big landowners and agribusiness in the states of São Paulo and Minas Gerais amounts to 1 million hectares. The peasants' organizations have been demanding their return to public ownership as part of their demand for land reform (Fernandes, 2000).

\section{THE NORTHEAST}

Half of Brazil's peasants live in the Northeast, where the lack of access to infrastructure and modern technology is the outstanding feature of the agrarian question. Most of the 88 percent of farms occupying 60 percent of the region's agricultural land are owned by families living in extreme poverty mitigated by policies such as the Bolsa Família (a federal monetary allowance paid to poor families whose children attend school). Many of these impoverished peasants migrate seasonally to the South to work cutting sugarcane and harvesting oranges and coffee. Despite their precarious economic conditions, these small farmers produce 70 percent of the region's rice, 79 percent of its black beans, 82 percent of its cassava, and 65 percent of its corn, crops that constitute an important part of the population's basic food supply. Despite their poverty, lack of technology, and limited landholdings, the peasants of the Northeast are responsible for much of Brazil's food security. The role of agribusiness here as elsewhere is producing commodities for export. The Northeast is decisively a region of export agriculture, a condition of which the "colonels" (the upstate rural landowners who run local politics and control the local economy) have always been the main beneficiaries. 
The exclusion of small farmers and their families in the Northeast from power and influence has increased as the expansion of soybean cultivation has led to land seizures in the states of Bahia, Maranhão, and Piaui. Recent land acquisition by foreign firms and governments, Chinese and Arab, has been adding new elements to the agrarian question (Fernandes, 2011; Sauer and Leite, 2012). The monoculture of trees to produce paper for export has also been causing loss of land by both peasants and indigenous people. For the think tanks of agribusiness, the Northeast is a region of only secondary importance: it has the most smallholdings and is responsible for only 20 percent of the GDP. If one starts from a logic that makes concentration and centralization its model, then the Northeast is clearly not ideal for agribusiness, but agribusiness is the sector whose capital has most appreciated in the region. Against this, the Northeast has had a history of conflict over landownership that goes back to the nineteenth century and the country's first real peasants' revolt, the Canudos War of 1896-1897.

\section{THE NORTH}

The North was the site of one of the most recent massacres of Brazilian peasants. On April 17, 1996, in Eldorado dos Carajás, Pará, 19 members of the MST were killed by the state military police when they tried to march on the state capital, Belém, to demand land reform. This eastern edge of the Amazon rain forest is the present-day agricultural frontier of Brazil, and its land is being contested for by indigenous people, small farmers, and agribusiness. Beef cattle and soybeans are the main local crops. At the same time, this is the region with the most extensive stretches of the public land that the federal government is using to strengthen its land reform policy. The government claims that it is reforming landownership by providing title to small farmers' landholdings, but it is common knowledge that this is not the sort of land reform that landless peasants want. The peasants insist that dispossession is the main way that they can obtain land. Two factors contribute to land reform's increasingly assuming the characteristics of an "agrarian regularization." The powerful agribusiness interests oppose land reform because they want to maintain a stock of idle land for the future expansion of their export agriculture, and the peasants lack the political power to force the government to carry out land reform by-mainly—seizing unused land.

In this context, land is disputed in the Amazon region because agribusiness wants to expand there but the indigenous people and the peasants are resisting this. The conflict on the Raposa Serra do Sol Reservation in Roraima is an instance of this type of land dispute. Agribusiness has been invading the reservation since the 1970s, planting thousands of acres there with rice. Indigenous opposition has had the support of peasant organizations, but Brazilian society has become divided over the question of land use. Agribusiness has been working hard to convince society that its production model is more up-to-date and efficient. Its use of advanced techniques and its considerable contribution to the nation's GDP is supposed to give it the right to take over land earmarked for indigenous and peasant occupation. In 2007 the Supreme Court ordered the rice growers to leave the reservation, a clear indication that only state intervention can safeguard indigenous peoples' and peasants' lands. From an economic perspective, agribusiness is overpowering, and its expansion involves the elimination of all other landholdings. 
In the Amazon region, the government has been investing in regularizing landownership, and this policy has provoked outrage because it has been splitting up the holdings of the big landowners into small pieces to fulfill the government's criteria. Such practices fit in with the government's land reform policies, as analyzed by Santos, Porro, and Porro (2011). The agrarian question is one of the great problems of the region and one that big landowners and capitalists take advantage of to expand their holdings. This is also the region with the highest rates of conflict that lead to fatalities. Because of its enormous size-half the national territory-it is a region of great interest to agribusiness even though it produces only 4.3 percent of the GDP. Its natural resources, its river systems, its mineral output, and its low population density all attract national and international corporations. With 87 percent of the country's farms but only 30 percent of its land, its small farmers nevertheless produce 53 percent of the rice, 89 percent of the black beans, 87 percent of the cassava, and 73 percent of the corn. Just as in the Northeast, the peasantry here in the Amazon is fundamental to guaranteeing the basic breadbasket of its inhabitants. Nevertheless, export crops have been expanding at the expense of peasant landholdings.

\section{THE CENTER-WEST}

The Center-West region is distinctive in the extent of agribusiness, the result of a settlement pattern that was reinforced by the policies of the military government during the 1964-1985 dictatorship, when capitalist enterprises benefited from subsidies that made possible a rapid occupation of the region. Although 69 percent of landholdings are small family farms, they amount to only 10 percent of the cultivable land. Soybean cultivation expanded rapidly in the 1980s, making this region Brazil's main producer. Agribusiness grows 98 percent of the soybeans, its most important crop, but it also dominates in growing rice and black beans, with peasant farmers contributing only 23 percent of the rice and 22 percent of the beans. Small farmers are more conspicuous in the production of cassava (55 percent) and coffee (62 percent). Agribusiness has established towns in which a commercial culture predominates, and this commerce contributes 14 percent of the GDP. The peasants have been losing more and more of their power to participate. The holdings they have been granted by land reform may be numerically large, but their contribution to the economy is quite small, only 2.9 percent of the region's output. This is a good example of the way the expansion of the agribusiness model drives the peasantry off the land and reduces its contribution to total output. The so-called modernization of agriculture now in vogue is based on the idea of eliminating a strategic sector of development, that of the peasantry, through policies that benefit the export monoculture that controls important regions of Brazil.

\section{CLOSING REMARKS}

This brief analysis shows that the potential for the peasantry to grow food is threatened by the concentration of power, landownership, capital, technology, and wealth. Its potential to increase its output, even if only as part of agribusiness, is clear. I have elsewhere (Fernandes, 2008b) suggested that family farming 
and agribusiness are different and should be treated as such. What I am proposing is not "sustainable capitalism" but a constant battle against the capitalist mode of production and a defense of the family, cooperative, community-based, associative modes of production in which decision-making power is shared. The political measures required to create such a situation will lead to conflict, but struggles for power, land, capital, technology, wealth, and so on, are inevitable.

Brazil's experiment with having two government ministries is an important step in creating a regulatory framework to shape policies on the development of family farming such as the Programa Nacional de Educação do Campo (National Rural Education Program) and the Programa Nacional de Educação na Reforma Agrária (National Program of Education in Land Reform) and marketing policies such as the Programa de Aquisição de Alimentos (Food Buying Program).

Looking at the situation by region makes it clear that the immediate prospect is increasing inequality in rural society if Brazil fails to change its development model. At the same time, there is no indication that such a change is going to happen. The way agriculture is developing is influenced by three factors: the continuing hegemony of agribusiness and the dependent status of family farming, the increasing political power of the peasants as they become better organized and united and propose to the federal government a development model that would strengthen peasant farming and safeguard the national food supply, and the introduction of agrarian legislation for zoning land use, separating land designated for producing commodities for export from land reserved for growing food for the home market.

The longer the dominance of agribusiness continues, the weaker the peasant agriculture sector becomes as more and more small farmers fail to earn enough to survive and new opportunities emerge for production to expand on territories expropriated from peasant ownership. Increasing the peasants' political power by strengthening their organizations and increasing support from civil society could change the direction of the current model of rural development, increasing the share of family farming in the value of the GDP. To achieve this it will be necessary to guarantee possession of their lands to the peasantry, the indigenous people, and the maroons (descendants of runaway slaves who settled in the wilderness of colonial Brazil), and this guarantee will require a national plan for zoning land available for agricultural production.

The chances of changing the current development model are slight, but the social and environmental problems it has created call upon the world community to think about the long-term future of the human race. The outlook for our peasants and indigenous people depends not just on how much political clout they can muster but on the model we pursue for the future of our planet.

\section{REFERENCES}

Abramovay, Ricardo

1992 Paradigmas do capitalismo agrário em questão. Campinas: Hucitec/ANPOCS/Editora da UNICAMP.

Alves, Eliseu and Daniela de Paulo Rocha

2010 “Ganhar tempo é possível?” pp. 275-290 in José García Gasques, José Eustáquio Ribeiro Vieira Filho, and Zander Navarro (eds.), A agricultura brasileira: Desempenho, desafios e perspectivas. Brasília: IPEA. 
Bruno, Regina

2008 "Agronegócio e os novos modelos de conflituosidade," pp. 83-105 in Bernardo Mançano Fernandes (ed.), Campesinato e agronegócio na América Latina: A questão agrária atual. São Paulo: Expressão Popular.

2012 "Movimento SOU AGRO: marketing, habitus e estratégias de poder do agronegócio." http://observatory-elites.org/wp-content/uploads/2012/06/Regina-Bruno.pdf (accessed September 15, 2013).

Castilho, Alceu Luís

2012 O partido da terra: Como os políticos conquistam o território brasileiro. São Paulo: Contexto.

CNA (Confederação da Agricultura e Pecuária do Brasil)

2010 Quem produz o que no campo, quanto e onde II: Censo agropecuário 2006, resultados, Brasil e regiões. Rio de Janeiro and Brasília: Fundação Getúlio Vargas, Instituto Brasileiro de Economia / Confederação da Agricultura e Pecuária do Brasil.

Costa, Sandra Helena Gonçalves

2012 "A questão agrária no Brasil e a bancada ruralista no Congresso Nacional." Master's thesis, Universidade de São Paulo.

Elden, Stuart

2010 "Land, terrain, territory." Progress in Human Geography 34: 799-817.

Fernandes, Bernardo Mançano

2000 A formação do MST no Brasil. Petrópolis: Editora Vozes.

2008a "Questão agrária: conflitualidade e desenvolvimento territorial," pp. 173-224 in Antônio Márcio Buainain (ed.), Luta pela terra, reforma agrária e gestão de conflitos no Brasil. Campinas: Editora da UNICAMP.

2008b Campesinato e agronegócio na América Latina: A questão agrária atual. São Paulo: Expressão Popular.

2008c "Entrando nos territórios do Território," pp. 273-302 in Eliane Tomiasi and João Fabrini (eds.), Campesinato e territórios em disputa. São Paulo: Expressão Popular.

2011 "Geopolítica da questão agrária mundial," pp. 1-4 in Tomás Sombini Druzian and Herivelto Fernandes Rochas (eds.), Cadernos conflitos no campo, Brasil 2008. São Paulo: Comissão Pastoral da Terra.

2013 "Construindo um estilo de pensamento na questão agrária: o debate paradigmático e o conhecimento geográfico." Reader's thesis, Universidade Estadual Paulista, Faculdade de Ciências e Tecnologia.

IBGE (Instituto Brasileiro de Geografia e Estatística)

2009a Censo agropecuário 2006: Brasil, grandes regiões e unidades da federação. Rio de Janeiro: IBGE. 2009b Censo agropecuário 2006: Agricultura familiar, primeiros resultados, Brasil, grandes regiões e unidades da federação. Rio de Janeiro: IBGE.

Martins, José de Souza

1986 O cativeiro da terra. São Paulo: Hucitec.

Navarro, Zander

2010 "A agricultura familiar no Brasil: entre a política e as transformações da vida econômica," pp. 185-212 in José García Gasques, José Eustáquio Ribeiro Vieira Filho, and Zander Navarro (eds.), A agricultura brasileira: Desempenho, desafios e perspectivas. Brasília: IPEA.

2013 "Fadas, duendes e agricultura." O Estado de S. Paulo, October 30.

Oliveira, Ariovaldo Umbelino

1991 A agricultura camponesa no Brasil. São Paulo: Contexto.

2003 "Barbárie e modernidade: as transformações no campo e o agronegócio no Brasil." Terra Livre 2 (21): 113-156.

Santos, Ione Vieira, Noemi Miyasaka Porro, and Roberto Porro

2011 Interventions to Curb Deforestation and Stability in Access to Land: A Comparative Study between Two Modalities of Land Regulation in the Transamazon Region, Brazil. Rome: International Land Coalition.

Sauer, Sergio and Sergio Leite

2012 "Agrarian structure, foreign investment in land, and land prices in Brazil." Journal of Peasant Studies 39: 873-898. 